\title{
Application of Green Construction Idea in Management of Architectural Engineering Project
}

\author{
Yuhai Miao ${ }^{1, \text { a }}$ \\ ${ }^{1}$ City Institute, Dalian University of Technology, Dalian City, Liaoning Province, 116600, China \\ aemail:
}

Key words: green construction; architecture engineering; project management; application

\begin{abstract}
As an important method and key link in the implementation of sustainable development strategy in the architecture industry, green construction has been understood and accepted by more and more people in the industry. How to promote the green construction in architecture industry, improve the sustainable development of the architecture industry, build a resource-saving and environment-friendly society is our common issue. Based on the author's learning and practical experience, this paper first analyzed the concept and connotation of green construction, and then discussed the development status of green construction, and finally analyzed the application of green construction in architectural engineering project management from the organization and management, construction management, technical management these aspects.
\end{abstract}

\section{Introduction}

China is still in the stage of rapid economic development, for such a large consumption of resources and affecting the environment of the architecture industry, it should follow the principle of act according to circumstances, and implement the national, industry and local relevant technical and economic policies, fully carry out green construction, to take the social responsibility of sustainable development. It exists many problems in green construction such as insufficient mobilization, lack of management, inadequate supervision and so on, which urgently need further improvement and to strengthen the green construction management.

\section{The concept and connotation of green construction}

green construction refers to during the construction of the project, under the premise of ensuring the quality, safety and other basic requirements, to maximize the resource saving and reducing the construction activities which have negative influence on environment through scientific management and technological progress, to achieve four saves and one environmental protection. "Green Construction Guide" as the guiding principle of green construction, clearly put forward that the overall framework of green construction is composed by construction management, environmental protection, materials saving and utilization, water saving and utilization, energy saving and use, land saving and protection six aspects. "Green construction" is no longer what the traditional construction process like, which required the quality of good, security insurance, construction civilization, corporate image, and no longer passively adapt to the requirements of traditional construction technology, it bases on the whole process of production, follows the concept of "four saves and one environmental protection", to plan the whole process of production, reform the traditional construction technology, improve the traditional management ideas, and maximize the effects of consumption, efficiency and environmental protection during the construction under the premise of ensure the quality and safety.

Green construction management is the application of sustainable development in the construction management, is also the comprehensive application of green construction management technologies. Green construction management technology is not a totally new technology which independent of the traditional construction management technology, but a construction management 
technology which is consistent with the sustainable development strategy, it just re-examines the traditional construction management technology with a "sustainable" vision. The core of the green construction management is using practical and effective management system and work system to minimize the adverse impacts of construction management activities on the environment and reduce the consumption of resources and energy, to achieve sustainable development construction management technology.

\section{Current development situation of green construction}

In the 1980s, under the guidance of circular economy and cleaner production thought, developed countries began to explore the practice of green construction, Japan, America, Germany and other developed countries have developed the corresponding laws, regulations, policies, so that the development of green construction is guaranteed by the system. In the 21st century, with the wide dissemination of the concept of sustainable development, China's architectural industry has a new understanding of green construction, construction companies first proposed a green construction suggestion, that green construction is a complex system engineering, realization of green construction not only solely rely on green construction technology, but also need to fully consider the construction situation environment, resource utilization, waste disposal and on-site construction organization and management and other factors. At present, the main part which implement green construction in China is architectural industries, but some of them did not take the green construction capacity as the competitiveness of enterprises, they failed to fully use the scientific management methods and take effective action to protect the environment and energy conservation, which only focused on completing the project objectives according to the construction contract, drawings and technical requirements, project plan and project budget, only concerned about the quality, safety, duration and cost, and rarely referred to green construction.

\section{Application of green construction in management of architectural engineering project}

Organization and management - green construction management foundation. Green construction is a complex system engineering, it involves the design units, construction units, construction enterprises and supervision enterprises, therefore, to truly realize green construction must coordinate all aspects of construction and every staff which involved, establish a green construction management system which take the project department as the intersection of "vertical and horizontal" two directions. That is, construction enterprises form the "vertical" management system according to "enterprises - project - construction company" and the "horizontal" management system involves in the construction unit leading, design institute, construction side and the supervision side participating. Only in this way can we include different organizations, different levels of personnel in the construction process into the green construction management system, to achieve the management mode of entire personnel, whole process, all direction and all level. Detailed work needs to start from the following aspects:

First: Enhance the propaganda and training of the concept of green construction and sustainable development. We should strengthen the propaganda and training of green construction, and guide enterprises to understand the green construction. Strengthen the technical and management personnel and first-line technical staff classification training, let workers correctly and fully understand the green construction through training, fully understand the importance of green construction and be familiar with the requirements of green construction, principles, methods, to enhance the sense of responsibility and urgency of implementing green construction, guarantee the implementation of green construction efficiency as soon as possible. Second: Develop enterprise green construction management system. According to the "green construction guide" and ISO14001 environmental certification requirements, combined with the characteristics of their own enterprises and construction characteristics, the system would consider the relationship and interaction among quality, environment, safety and cost to develop enterprise green construction management system, 
and establish the green construction performance appraisal system based on project manager leading, to form enterprises' own green construction management standards and implementation guidelines. Third: Establish the green construction management agencies of enterprises and project departments. Designate green construction management and supervision personnel, clarify each levels management personnel's duty, strictly follow the enterprise system to manage. Fourth: Establish green construction evaluation index system. Considering the importance of each stage of construction and influencing factors, we should formulate enterprise own evaluation method and evaluation system of green construction by referring to the relevant green construction evaluation system.

Green construction also need to establish a construction unit for the coordination of units, design, construction, supervision and other units which participated in the "horizontal" management system. Construction units should clearly tell design and construction units the detailed demands of green building design and green construction, also provide space, time, duration and other security conditions, organize and coordinate the construction of green construction management work; design units select the material should take the green building design standards and requirements as reference, initially make the whole design explanation to the construction unit; supervision units should be responsible for the supervision of green construction management of the project, review green construction programs and detailed construction measures of the overall program, and to implement the supervision and checking work during the construction.

Implementation management - key point of green construction management. Implementation management is the planning, implementation and control of the green construction program in the whole construction process, is an important part of the implementation of green construction, is also the significant content for the enterprise to achieve "low cost, high quality". Its management measures and means mainly include:

First: Clarify control points. Combined with the characteristics of the project and the construction process, clarify green construction control objectives and on-site construction process control objectives, etc., to strengthen management personnel's understanding about the control objectives, take the control objectives as the limitation of actual management to operate.

Second: Implement the dynamic management. In the construction process, collect the measured data in various stages of green construction control, and compare the actual measurement data with controlled objectives on a regular basis, when problems occur, we should analyze the reason, from the organization, management, economy, technology and other aspects to develop corrective and preventive measures and implement them, gradually realize the green construction management objectives.

Third: Develop special management measures. According to the green construction control points, develop detailed assurance measures in each stage of green construction, such as: water conservation measures, materials conservation measures, energy and land conservation measures, environmental protection measures, personnel safety and health measures, and strengthen the propaganda and education of first-line management personnel and operators. At present, large enterprises have their own green construction management procedures, but the key is to implement.

Project management personnel must implement every requirement of the green construction to the site management, process management, on-site management and other management. Only each part involved in the construction follows the requirements of the green construction and do a good job in every aspect of green construction, can the level of green construction be continuously improved.

Technical management - guarantee for green construction management. Green construction technology measure is the control method and technical measure in the construction process, which is the technical support for achieving the green construction objectives. The formulation of green construction technology measures should be in accordance with national and local relevant laws and mandatory regulations, according to the "green construction guidelines" and relevant regulation requirements, combined with the project characteristics, on-site construction situation and the actual technical capacity of construction enterprise, measures should be targeted and practical. 
First, vigorously promote the use of new technologies of green construction. Enterprises should establish incentive mechanism for innovation, increase investment in science and technology, greatly promote the development and research of green construction technology, to combine engineering and scientific research, and continuously enhance the ability of independent innovation, promote the use of new technology, new craft, new material, new equipment. Large-scale construction enterprises should gradually update the machine and equipment, develop construction design, and closely combine the design and construction, to form a patented technology with enterprise characteristics. Small and medium enterprises should actively introduce, digest, apply advanced technology and management experience. In fact, the application of green construction technology is much more economical than traditional construction.

Second, make use of information technology, improve the level of green construction management. One of the effective ways of green construction in developed countries is informational construction, which is a kind of green construction method which adopts dynamic parameters to implement quantitative and dynamic construction management. The workload of construction changes dynamically, then the input of construction resources would also change. To adapt such changes, we must use informational technology, relying on dynamic parameters, implement quantitative and dynamic construction management, to complete the project tasks with minimal resources, in order to achieve high efficiency, low consumption and environmental protection purposes.

\section{Conclusion}

Green construction management is an important method in the green construction process, its purpose is to implement the green construction concept in the whole construction process, truly realize the green construction concept in the practical construction process, to ensure achieving the overall goal of green construction and promote the sustainable development of the construction industry, make due contributions to the resource-saving and environment-friendly society establishment.

\section{References}

[1] Lu Ning, Li Lin, Xie Yanping. Study on earned value method of construction project safety management [J]. Journal of China Safety Science, 2013, (03): 145-149.

[2] Cui Jingshan, Wang Dong, Liu Fei, Yang Ming, Xiao Hong. Application of "ten points" of green construction in construction project management [J]. Construction Technology, 2012, (21): 4-7.

[3] Zheng Yong. Application of green building construction technology in large-scale railway hub project [J]. Construction, 2010, (10): 1074-1075 + 1079.

[4] Lu Rongli. Study on green construction management of construction project [J]. Construction Economy, 2010, (03): 104-107.

[5] Wang Guoping, Gu Weiming, Xia Genrong, Zhou Yanfei. Discussion on the green construction concept in the construction project management [J]. Special Structures, 2009, (06): 110-113.

[6] Zhou Hongbo, Yao Hao, Lang HaoChuan. Management planning and application research on existing building renovation green construction management planning and application research [J]. Construction Economy, 2008, (05): 27-30. 